\title{
AN ENTREPRENEURSHIP EDUCATION MODEL FOR PROMOTING STUDENTS' ENTREPRENEURIAL INTENTIONS: THE CASE OF INDONESIAN HIGHER EDUCATION
}

\author{
Ambara Purusottama*11 and Teuku Fajar Akbar*) \\ *) School of Business and Economics, Department of Business, Universitas Prasetiya Mulya \\ Jl. RA. Kartini (TB Simatupang), West Cilandak, East Jakarta 12430
}

\begin{abstract}
This study aimed to provide an understanding and evaluating the implementation of entrepreneurship education as a mandatory program in Indonesia. The study emphasizes the measurement of the effectiveness of different entrepreneurship education programs in higher education implementation, intracurricular and cocurricular programs. The study used the Theory of Planned Behavior (TPB) to measure students' entrepreneurial intentions. The objects of the research were students who participated in the entrepreneurship programs. The study used quantitative approach and purposive sampling as the sampling technique. The survey resulted in 304 valid respondents from ten universities in Indonesia. The findings showed that intracurricular-based entrepreneurship education was unable to give a significant emphasis on students' entrepreneurial intention. In contrast, cocurricular-based entrepreneurship education was able to give a significant emphasis on students' entrepreneurial intention and emphasized on attitude as a single factor.
\end{abstract}

Keywords: entrepreneurship education, theory of planned behavior, intracurricular, cocurricular, entrepreneurial intention

\begin{abstract}
Abstrak: Penelitian ini bertujuan memberikan pemahaman dan mengevaluasi penerapan pendidikan kewirausahaan di tengah masifnya dorongan kewirausahaan yang bersifat mandatori di Indonesia. Studi ini menekankan pada efektivitas implementasi program pendidikan kewirausahaan yang berbeda-beda di pendidikan tinggi, program intrakurikuler dan kokurikuler. Penelitian ini menggunakan Theory of Planned Behavior (TPB) untuk mengukur perilaku kewirausahaan mahasiswa. Peneliti menyasar mahasiswa yang merupakan bagian dari program kewirausahaan sebagai objek penelitian. Penelitian ini menggunakan pendekatan kuantitatif dan purposive sampling sebagai teknik pengambilan data. Survei menghasilkan 304 responden yang berasal dari sepuluh universitas di Indonesia. Temuan menunjukkan bahwa pendidikan kewirausahaan berbasis intrakurikuler tidak mampu memberikan penekanan yang signifikan terhadap keminatan berwirausaha mahasiswa. Sebaliknya, pendidikan kewirausahaan berbasis kokurikuler justru mampu memberikan penekanan signifikan terhadap keminatan kewirausahaan dan faktor sikap menjadi faktor yang paling memberikan pengaruh bagi mahasiswa.
\end{abstract}

Kata kunci: pendidikan kewirausahaan, theory of planned behavior, intrakurikuler, kokurikuler, keinginan berwirausaha

\footnotetext{
${ }^{1}$ Corresponding author:

Email: ambara.purusottama@pmbs.ac.id
} 


\section{INTRODUCTION}

As time passes by, the contribution of education has been made functional to entrepreneurial activities. Hanushek (2016) discusses the fundamental role of education as a welfare booster. They agree that good cognitive abilities are effective ammunitions. In short, an individual with a good educational background has a higher probability to be more prosperous in terms of his or her well-being. The enrichment of human skills and knowledge through education is able to create innovation and adaptation of technology which ultimately leads to the increase of income (Guerrero et al. 2014). As firmly stated by Liñán et al. (2011), entrepreneurship education is a key role instrument to enhance potential entrepreneurial attitude as well as potential new entrepreneurs. Nevertheless, other discussions state that a final agreement to the contributing factors of individual judgment which can influence the decision to be an entrepreneur has not been reached (Bae et al. 2014).

The application of entrepeneurship education in Indonesia has just started to show its benefit nowadays. Through the Indonesian National Education Standards (SNP) as stipulated in the Presidential Decree (Perpres) No.19/2005, entrepreneurship education can be promoted and can be given from an early age. This effort is carried out to help strengthen the nation's economy and to be a stimulus in creating competitive individuals in facing globalization challenges such as the ASEAN Economic Community (Imaroh, 2014). In practice, SNP will be a reference for every educational institution in Indonesia to shape the pattern of education and its curriculum so that it can be understood and practiced in daily life.

Many studies have supported the importance of entrepreneurship education, one of which is that of Souitaris et al. (2007) summarizing that education has a significant and measurable impact in entrepreneurial activities. The concrete relationship among activities such as education, job creation, and entrepreneurial performances most certainly confirms the notion that education is indeed a vital aspect of entrepreneurial activities (Paco et al. 2011). The education system that is built will ultimately affect some factors such as basic knowledge, skills, competencies, and ways the students choose their career paths. Obviously, schools have the obligation to direct students regardless of the career path they choose, including to be an entrepreneur. Pittaway and Cope (2016) discover that education has given an intense impact on the students' tendencies and intentions in the context of entrepreneurship. Indeed, in the real word, education has proved to have a critical effect on students in their endeavor to stimulate job creation.

The importance of education in entrepreneurial activities faces certain challenges. In some literature, education empirically does not always support entrepreneurship. Fayolle and Gailly (2015) argue that entrepreneurship education will only have a significant impact on individuals who have never received such education. Meanwhile, Oosterbeek et al. (2010), Matlay (2008) and Graevenitz et al. (2010) similarly deny education support and emphasize that education does not have a positive influence on entrepreneurial skills, and it tends to have negative implications. Similarly, Küttim et al. (2014) explain that entrepreneurship education only contributes a relatively small deal towards entrepreneurial intentions. Zhang et al. (2013) argue that the differences in educational backgrounds do not always have a direct effect towards the students' entrepreneurial intentions. In other words, the inclusion of entrepreneurship education does not guarantee a positive outcome. In some worst-case conditions, it could even go the other way i.e. resulting in a negative outcome.

Several models have been developed and utilized to examine entrepreneurial behavior. Theory of Planned Behavior (TPB) is well-known theory widely used to measure entrepreneurial behaviour (Ajzen and Sheikh, 2016). However, many studies on entrepreneurial behavior Arnis et al. (2018) encountered distinct difficulties. This might happen due to many factors that affect individual behavior. Studies on behavior often put more emphasis on activities than on individual behavior or intentions. Ferreira et al. (2012) conclude that the ability to predict intention is more measurable than behavior. In practice, behavior does not always have to be in line with intention because behavior allows the cancellation of the initial intention. Moreover, intentions that form early-behaviors are positioned as behavioral predictors (Kolvereid and Isaksen, 2006). With regard to entrepreneurship, intention has been widely used as a measuring unit of personal orientation, delegation of tasks, or interests that lead to the creation of ideas and business development (Thompson, 2009). Up to now, individual entrepreneurial intentions are the main drivers of the research on the formation of new businesses. 
Entrepreneurship as the key driver of the economy has grown significantly in recent years, including entrepreneurial intervention in the education sector. Therefore, this massive push needs to be evaluated because, in the global context, the effectiveness of each entrepreneurial education is still debatable and cannot be concluded until now. Although the application of entrepreneurship education in Indonesia is a mandatory program, the limited scope of science in higher education has led to the implementation of different programs: intracurricular and cocurricular.

The present study used TPB to measure the entrepreneurial intentions of students who are exposed to education and through a cross-sectional study. The research instrument was adapted from previous research by making several adjustments to be easily understood by the respondents.

Research questions: To what extent does the higher education system in Indonesia encourage students' entrepreneurial intentions?; How does Indonesian higher education stimulate students' entrepreneurial interests?; Do the different forms of education (intracurricular and cocurricular programs) influence students' interests in entrepreneurship? If there is, what is the difference?

\section{METHODS}

This study used a quantitative approach with purposive sampling as the data collection technique. The duration of the study took six months in the odd semester 2018/2019 learning period. Offline questionnaires were disseminated simultaneously to university students. Questionnaires were distributed according to the networks owned by the researchers. The units of analysis in this study were students who were exposed to entrepreneurship education both through intra-curricular and co-curricular studies from several universities in Indonesia. 305 questionnaires were collected from ten leading universities in Indonesia. Out of 305, 304 valid questionnaires were produced. The models were tested using structural equation modeling.

Hypothesis development was based on a TPB. TPB stated that there are three factors that influence students' entrepreneurial intention, starting from new venture and self-employment. These three factors include attitude, subjective norms, and behavioral control. TPB high-lights that entrepreneurial interests are also in line with these three influencing factors: The more positive the influencing factors, the more positive the students' intention to enterprise.

Attitude(ATT) is a response to something that is obtained or learned from entrepreneurial activities (Kautonen et al. 2015). The resulting response can be either a positive or a negative response depending on how the individual receives it. In other words, being an entrepreneur does not always produce positive perceptions. It can also be negative depending on the consequences resulting from their decision (Ajzen, 2005). By definition, attitude represents an evaluation of a psychological object that is captured in the contested attribute dimension, both positive and negative. The shift in confidence can occur because of the valence of beliefs that exist at a certain time. The studies conducted by Ferreira et al. (2012) and Solesvik et al. (2012) agree that only if entrepreneurship education provides benefits for him, the individual will respond accordingly, e.g. choosing a career as an entrepreneur (Souitaris et al. 2007).

Ha1 : Entrepreneurship education contributes significantly and positively to the relationship between attitude towards intention to value creation.

Ha2 : Entrepreneurship education contributes significantly and positively to the relationship between attitude towards selfemployment.

Social pressure is a measuring tool to determine the relationship of social interaction. In TPB, the social pressure in question is known as the Subjective Norm (SN). $\mathrm{SN}$ is the reference to perceptions arising from the influence of others around the individual. $\mathrm{SN}$ is used in measuring entrepreneurship within a parameter of social pressure generated in the context of entrepreneurial activities (Liñán et al. 2011). Ajzen (2005) explains that $\mathrm{SN}$ of a person is a perception or opinion that is built from another individual whom $\mathrm{s} / \mathrm{he}$ considers as an important individual who is heard and followed as a role model. The study conducted by Maes et al. (2014) confirms SN has a significant influence on individual behavior besides ATT. In entrepreneurial activities, individuals will be strongly influenced by other individuals whom they considered as important. These important individuals are expected to be able to deal directly to an individual like a family member, 
and indirectly such as role models or idols. Opinions on entrepreneurship from these so-called important individuals will influence others as a form of social pressure.

Ha3 : Entrepreneurship education contributes significantly and positively to the relationship between subjective norm towards intention to value creation.

Ha4 : Entrepreneurship education contributes significantly and positively to the relationship between subjective norm towards self-employment.

In addition to being influenced by ATT and SN, individual behavior is also driven by the control of will known as behavioral control (PBC) (Ajzen, 2005). In Ajzen's theory, it is explained that $\mathrm{PBC}$ is an individual perception that is built with regard to the ease and difficulty in carrying out the individual's desires. This perception is built based on a reflection of past experience and anticipation of future challenges. A positive $\mathrm{PBC}$ means that the individual considers his actions to be conducted because of a positive experience, and it has the capacity to do it and is ready to accept the potential risks. PBC is another form of self-efficacy which is a belief in an individual's ability to achieve the determined results (Armitage and Conner, 2001). (Liñán et al. 2011) defines PBC as a perceived ease and difficulty in conducting entrepreneurial activities.

Ha5 : Entrepreneurship education contributes significantly and positively to the relationship betweenperceived behavioural control toward intention to value creation.

Ha6 : Entrepreneurship education contributes significantly and positively to the relationship between perceived behavioral control toward self-employment.

Figure 1 illustrates the research framework developed. TPB acts as an instrument for measuring student behavior towards exposure to entrepreneurship education. In developing the structural equation model, we used an entrepreneurial based education variable approach to measure students' entrepreneurial intentions from several factors that influence behavior, namely, attitude, subjective norms, and perceived behavioral control. Furthermore, we used control variables in the form of intra-curricular and co-curricular which were then compared between them to answer the purpose of this study.

The statements in the questionnaires were measured by using a 5-points Likert scales ranging from 1 "strongly disagree" to 5 "strongly agree" (Weijters et al., 2010). The Structural Equation Model (SEM) is used to show the interconnectedness of the variables which is in line with that of Hair et al. (2010) in which the research equation used the reciprocal inter-connectedness among the constructs involved in the analysis. The AMOS application is used to analyze the moment structure to estimate structural equation models developed and integrated directly with other existing statistical applications, i.e. SPSS.

In addition, the measurement tools refers to those of the previous research adjusted (and translated) into the Indonesian Language to facilitate the respondents in interpreting the given statements. The entrepreneurial interest was measured by using the Likert scale. To measure ATT behavior, a four-item statement was adopted from Liñán and Chen (2009) and Solesvik (2012) and was used to ask the students' opinions on entrepreneurship and on whether or not being an entrepreneur is considered attractive or desirable.

A four-item statement adopted from Solesvik (2012) and Souitaris et al. (2007) is also used to measure the SN. In this variable, students are asked to rate how far the influence of people whom they consider important such as family members, friends, role models, or idols could influence their intention to enterprise. A four-item statement to measure PBC is adopted from Solesvik (2012), Souitaris et al. (2007), and Liñán and Chen (2009). The PBC statements contain items that reflect the students' comfort or inconvenience of entrepreneurship and self-employment.

Students' entrepreneurial intentions and selfemployment as well as each latent variable, were measured by using a five-item statement. These statements were adopted from Liñán and Chen (2009) and Solesvik (2012) which focused on students' intention to start new venture and self-employment. The details of research instrument show on Table 1. 


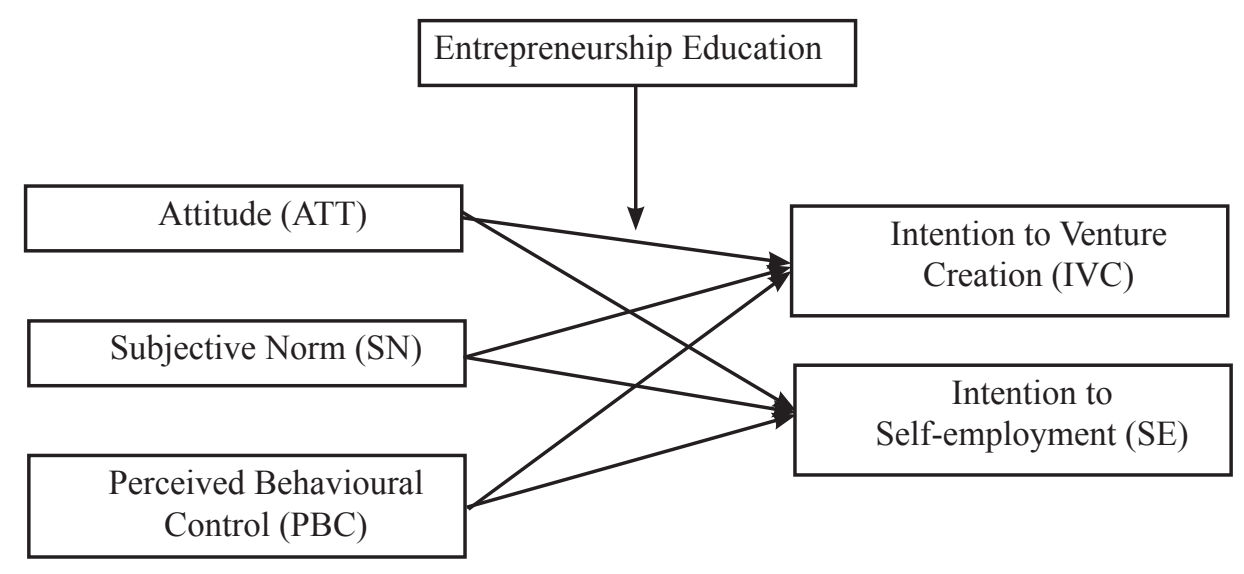

Figure 1. Research framework

Tab1e 1. Research instrument

\begin{tabular}{|c|c|c|}
\hline Variable & Statements & Code \\
\hline \multirow{4}{*}{$\begin{array}{l}\text { Attitude } \\
\text { (att) }\end{array}$} & Entrepreneurship provides benefits for me & att_1 \\
\hline & I understand how to do business & att_2 \\
\hline & I am ready to accept the risks in entrepreneurship & att_3 \\
\hline & Starting a business is challenging for me & att_4 \\
\hline \multirow{4}{*}{$\begin{array}{l}\text { Subjective Norm } \\
(\mathrm{sn})\end{array}$} & When deciding to become entrepreneur, I am influenced by my colleagues & sn_1 \\
\hline & Other people's opinions are important for me in implementing entrepreneurship & sn_2 \\
\hline & $\begin{array}{l}\text { The opinion of the closest persons like my family and friends is important for me in } \\
\text { implementing entrepreneurship }\end{array}$ & sn_3 \\
\hline & The encouragement of others is important for me to start an entrepreneurial journey & sn_4 \\
\hline \multirow{4}{*}{$\begin{array}{l}\text { Perceived Behavioral } \\
\text { Control (pbc) }\end{array}$} & If I want, I can easily start my business & pbc_1 \\
\hline & I will be the decision maker to conduct entrepreneurial activities or not & pbc_2 \\
\hline & I have full control of the business that I will run & pbc_3 \\
\hline & Even though it is risky, I will continue to start a business & pbc_4 \\
\hline \multirow{5}{*}{$\begin{array}{l}\text { Intention to Value } \\
\text { Creation (ivc) }\end{array}$} & I want to start my business immediately & ivc_1 \\
\hline & I want to start my own business if I have sufficient resources & ivc_2 \\
\hline & I will do anything to start my own business & ivc_3 \\
\hline & I have strong determination to conduct my own business & ivc_4 \\
\hline & I am serious about starting my own business & ivc_5 \\
\hline \multirow[t]{5}{*}{$\begin{array}{l}\text { Self-employment } \\
\text { (se) }\end{array}$} & $\begin{array}{l}\text { I will be proud of being self-employed or entrepreneur even though I am just a } \\
\text { beginner }\end{array}$ & se_1 \\
\hline & $\begin{array}{l}\text { I am more interested in being self-employed or entrepreneur than in any other } \\
\text { professions }\end{array}$ & se $\_2$ \\
\hline & Being self-employed or entrepreneur means a lot to me & se_3 \\
\hline & My dream is to become a self-employed entrepreneur & se_4 \\
\hline & Being self-employed or entrepreneur is more beneficial for me & se_5 \\
\hline
\end{tabular}

\section{RESULT}

The respondents were chosen from ten universities in Java and Sumatra, Indonesia. Based on the demographic data, there were 156 male respondents and 148 female respondents coming from ten different universities with balanced proportions. To achieve the research objectives, an assessment was conducted to classify their educational background and also their length of study. There were 135 respondents majoring in management education and had entrepreneurship education backgrounds classified as intracurricular. The other 169 respondents were classified as cocurricular. The classification of majors was aimed at differentiating the 
intracurricular curriculum with that of the cocurricular. Based on the year of study, there were four categories: the first year (41 respondents), the second year (135 respondents), the third year (45 respondents), and the fourth year (83 respondents). Profile of respondents in Table 2.

Validity, discriminant validity and reliability

The survey data had been tested and stated in accordance with the required conditions. Data reliability or construct reliability $(\mathrm{CR})$ on each latent variable met the requirements of $>0.6$. The $\mathrm{CR}$ values on ATT was 0.738 , SN 0.785, PBC 0.895, IVC 0.821, and SE 0.918 . The results of data validity indicators or Average Variance Extracted (AVE) are also in accordance with the provisions of $>0.5$, ATT with 0.501 , SN with 0.520 , PBC with 0.663 , IVC with 0.561 , and SE with 0.700 . Therefore, the data from the results of testing validity and reliability met the requirements (Table 3 ).

The value of discriminant validity in the exogenous variables of the study met the data validity requirement (see Table 3). The value of discriminant validity which is the square root value of AVE was higher than the correlation value of the other latent variables. The values of discriminant validity in the ATT, SN, and PBC variables were $0.708,0.721$, and 0.814 respectively. This number was higher than ATT $<->$ SN (0.383), ATT <-> PBC (-0.095), and PBC <-> SN (-0.114). Therefore, it can be concluded that the data correlation between exogenous variables is valid.

Table 2. Profile of respondents

\begin{tabular}{|c|c|c|c|}
\hline Characteristics & & Frequency & $(\%)$ \\
\hline \multirow[t]{2}{*}{ Gender } & Male & 156 & $51.3 \%$ \\
\hline & Female & 148 & $48.7 \%$ \\
\hline \multirow[t]{10}{*}{ University origin } & Universitas Atma Jaya & 34 & $11.2 \%$ \\
\hline & Universitas Prasetiya Mulya & 28 & $9.2 \%$ \\
\hline & Universitas Indonesia & 30 & $9.9 \%$ \\
\hline & Universitas Surya & 30 & $9.9 \%$ \\
\hline & Universitas Kristen Satya Wacana & 33 & $10.9 \%$ \\
\hline & Universitas Pelita Harapan & 30 & $9.9 \%$ \\
\hline & Universitas Pembangunan Jaya & 29 & $9.5 \%$ \\
\hline & Universitas Sriwijaya & 30 & $9.9 \%$ \\
\hline & Universitas Multimedia Nusantara & 30 & $9.9 \%$ \\
\hline & Universitas Bina Nusantara & 30 & $9.9 \%$ \\
\hline \multirow[t]{2}{*}{ Major study } & Intracurricular (Management and Entrepreneurship) & 135 & $44.4 \%$ \\
\hline & Cocurricular (Non-Management and Entrepreneurship) & 169 & $55.6 \%$ \\
\hline \multirow[t]{4}{*}{ Year of study } & First & 41 & $13.5 \%$ \\
\hline & Second & 135 & $44.4 \%$ \\
\hline & Third & 45 & $14.8 \%$ \\
\hline & Fourth & 83 & $27.3 \%$ \\
\hline
\end{tabular}

Table 3. Validity, discriminant validity and reliability testing

\begin{tabular}{llcccc}
\hline & ATT & SN & PBC & IVC & SE \\
\hline CR & 0.738 & 0.785 & 0.895 & 0.821 & 0.918 \\
AVE & 0.501 & 0.520 & 0.663 & 0.561 & 0.700 \\
ATT & 0.708 & 0.383 & -0.095 & & \\
SN & 0.383 & 0.721 & -0.114 & & \\
PBC & -0.095 & -0.114 & 0.814 & & \\
& Fourth & 83 & $27.3 \%$ & & \\
\hline
\end{tabular}




\section{Goodness-of-fit}

Some adjustments were made to achieve a decent model. The adjustments were conducted by reducing the observation variable of each latent variable. The reduction was based on a low correlation value. In exogenous variables such as ATT, SN, and PBC, one observation variable with the lowest value was omitted, whereas in the endogenous variables, IVC and SE, two observation variables were omitted. Thus, each latent variable had only three observation variables. The reduction made the indicators of goodness of fit have better results (Table 4).

The results of goodness-of-fit indicators fitted the required values. The CMIN/df value produced 2.286 , lower than the required $\leq 2-5$. The other indicators, CFI, TLI, RMR, RMSEA, and GFI, were able to produce output which fitted the required values: CFI with 0.947 $(>0.92)$, TLI with $0.932(>0.92)$, RMR with 0.044 $(<0.08)$, RMSEA with $0.065(<0.08)$ and GFI 0.924 (> $0.90)$. Consequently, the model met the requirements of a model.

\section{Hypothesis testing}

\section{General hyphotesis}

The general hypothesis testing produced varying results (Table 5). The relationship between ATT and its endogenous variables, IVC and SE, was significant with the P-value of 0.000 . There is a significant relationship between $\mathrm{SN}$ and IVC, and between $\mathrm{SN}$ and SE, although there were differences between the two variables. The relationship between $\mathrm{PBC}$ and IVC had a P-value of 0.042, and the P-value of SN and SE was 0.027 . Finally, the relationship between $\mathrm{PBC}$ and its endogenous variables did not have a significant relationship because the P-value did not meet the required $\mathrm{P}$-values for a significant relationship. Thus, it can be concluded that the hypotheses in $\mathrm{H} 1, \mathrm{H} 2, \mathrm{H} 3$, and $\mathrm{H} 4$ are accepted while $\mathrm{H} 5$ and $\mathrm{H} 6$ are rejected.

The test results showed the strongest relationships between the ATT and IVC, and between the ATT and SE, since their coefficient values were the highest of all the other variables i.e. 0.956 and 1.035 respectively. The next strongest variable coefficient was $\mathrm{SN}$ and its endogenous variable. SN with IVC had a coefficient value of -0.208 , and $\mathrm{SN}$ with $\mathrm{SE}$ had a value of -0.250 . However, the relationship of SE and IVC and SE had a reverse relationship indicated by a negative coefficient value. The relationship between $\mathrm{PBC}$ variables and its endogenous variables has a different relationship among the variables. The coefficient value of $\mathrm{PBC}$ on IVC had a value of 0.060 , and $\mathrm{PBC}$ against $\mathrm{SE}$ was at -0.024 . However, the relationship between PBC and its endogenous variables did not have a significant relationship.

Intracurricular and cocurricular hypothesis

The hypothesis of entrepreneurship education interventions was based on two program types i.e. intracurricular and cocurricular. Different results were produced between the two as shown in Table 6. The intracuricular program showed that none of the variables had a significant relationship. The relationship between ATT and its endogenous variables, IVC and SE, only produced a $\mathrm{P}$ value of 0.098 and 0.081 respectively. Then, SN for IVC and SE produced a P-value of 0.147 and 0.266 respectively. PBC for IVC and SE produced a P-value of 0.411 and 0.826 . The relationship between variables was unable to fit the required values of $<$ $0,001,<0,01$, or $<0,05$. It can be concluded that the intracurricular-based program hypothesis is rejected.

Table 4. Goodness-of-fit results

\begin{tabular}{lccc}
\hline Goodness-of-fit Measurement & Match Level Target & Estimation Result & Fit Measurement \\
\hline X2 & $\leq 2-5$ & $\mathrm{X} 2 / \mathrm{df}=2.286$ & Good fit \\
CFI & $>.92$ & 0.947 & Good Fit \\
TLI & $>.92$ & 0.932 & Good Fit \\
RMR & $\leq 0.08$ & 0.044 & Good Fit \\
RMSEA & $<.08$ & 0.065 & Good Fit \\
GFI & $>.90$ & 0.924 & Good Fit \\
\hline
\end{tabular}


Table 5. Hypothesis test result

\begin{tabular}{lcccc}
\hline Hypothesis & Relationship & Estimate $(\mathrm{S})$ & P-Value & Decision \\
\hline Ha1 & ATT $\rightarrow$ IVC & 0,956 & 0,000 & Supported*** \\
Ha2 & ATT $\rightarrow$ SE & 1,035 & 0,000 & Supported*** \\
Ha3 & SN $\rightarrow$ IVC & $-0,177$ & 0,042 & Supported* \\
Ha4 & $\mathrm{SN} \rightarrow$ SE & $-0,160$ & 0,027 & Supported* \\
Ha5 & PBC $\rightarrow$ IVC & 0,060 & 0,518 & Not Supported \\
Ha6 & PBC $\rightarrow$ SE & $-0,024$ & 0,801 & Not Supported \\
\hline
\end{tabular}

*significant at 0,$05 ; * *$ significant at 0,$01 ; * * *$ significant at 0,001

Table 6. Intracurricular and cocurricular based hypotheses

\begin{tabular}{lllccccc}
\hline \multirow{2}{*}{ Hypothesis } & \multirow{2}{*}{ Relationship } & \multicolumn{2}{c}{ Estimate $(\mathrm{S})$} & \multicolumn{2}{c}{ P-Value } & \multicolumn{2}{c}{ Decision } \\
\cline { 3 - 7 } & & Intra & Co & Intra & Co & Intra & Co \\
\hline Ha1 & ATT $\rightarrow$ IVC & 0,950 & 0,958 & 0,098 & 0,000 & Not Supported & Supported*** \\
Ha2 & ATT $\rightarrow$ SE & 1,073 & 1,019 & 0,081 & 0,000 & Not Supported & Supported*** \\
Ha3 & SN $\rightarrow$ IVC & $-0,629$ & $-0,141$ & 0,147 & 0,145 & Not Supported & Not Supported \\
Ha4 & SN $\rightarrow$ SE & $-0,436$ & $-0,126$ & 0,266 & 0,192 & Not Supported & Not Supported \\
Ha5 & PBC $\rightarrow$ IVC & 0,301 & 0,051 & 0,411 & 0,620 & Not Supported & Not Supported \\
Ha6 & PBC $\rightarrow$ SE & 0,084 & $-0,005$ & 0,826 & 0,958 & Not Supported & Not Supported \\
\hline
\end{tabular}

*significant at 0,$05 ; * *$ significant at 0,$01 ; * * *$ significant at 0,001

The opposite condition applied to the cocurricularbased programs. The relationship between ATT and IVC and SE had a significant relationship; therefore, $\mathrm{Ha} 1$ and $\mathrm{Ha} 2$ are accepted. ATT and its endogenous variables had a P-value that fitted the requirement, which was significant at 0.001 . The relationship of the other variables, SN and PBC towards its endogenous variables caused the entire hypothesis to be rejected. $\mathrm{SN}$ toward its endogenous variables, IVC and SE produced a P-value of 0.145 and 0.192 , whereas $\mathrm{PBC}$ toward IVC and SE produced P-values of 0.620 and 0.958 , respectively. The P-value generated from those relationship was unable to fit the requirement.

The comparison of hypotheses between intracurricular and cocurricular programs concluded that the relationship between ATT to IVC and SE in the cocurricular program was the only significant relationship. Therefore, it can be ascertained that the ATT coefficient value toward IVC and SE in the cocurricular based program is the only coefficient value that appears from the model test.

The data showed that the intervention of entrepreneurship education applied in higher education is able to give a positive emphasis in terms of attitudes and subjective norms as well. Nevertheless, it is not able to influence the behavioral control factor. These results support the research conducted by Solesvik (2012). According to them, entrepreneurship education has a significant influence on attitude and control behavior. However, the findings resulted in an emphasis on attitudes and lack of behavioral control in influencing students' entrepreneurial intentions. The research findings also concur the opinion of Fayolle and Gailly (2015) and Souitaris et al. (2007) that the subjective norms produce relationships that are opposite to or have a negative relationship. This value implies that there is a discrepancy between personal opinion and the social environment and between personal opinion and the entrepreneurial intention. The social environment that is not exposed to entrepreneurship is the main cause of inconsistency between individuals and their environment.

The intracurricular-based programs showed that entrepreneurship education was unable to emphasize the students' entrepreneurial intention. The finding reinforced those of several studies that reveal that entrepreneurship education does not have a positive impact on the interest in entrepreneurship (Matlay, 2008; Graevenitz et al. 2010; Oosterbeek et al. 2010). In other words, the implementation of entrepreneurship education taken through the intracurricular-based program work is ineffective. On the contrary, the cocurricular-based program is able to emphasize the 
attitude of students towards students' entrepreneurial intention. The finding reinforces the result of the study by Fayolle and Gailly (2015) which states that more impact will be absorbed by individuals who have never been exposed to entrepreneurship education than by individuals who have been exposed to entrepreneurship education.

\section{Managerial Implication}

The findings contribute to the theory of behavior towards education and have broader implications on the entrepreneurship education. The results of the study can also be used as a reference for the stakeholders to improve and seek a more effective model in an effort to encourage students' entrepreneurial intention.

\section{CONCLUSIONS AND RECOMMENDATIONS}

\section{Conclusions}

Entrepreneurship education has influenced the students' entrepreneurial intention. The emphasis on subjective attitudes and subjective norms is felt by students. However, entrepreneurship education applied in higher education is more effective in cocurricular-based program compared to intracurricular-based program. Based on the TPB framework, the intracurricularbased program does not have a significant impact on the three influencing factors: attitudes, subjective norms, and behavioral control. On the contrary, the cocurricular-based program is able to form a positive attitude towards the students' entrepreneurship desires. Nevertheless, entrepreneurship education in cocurricular-based programs is unable to emphasize other factors: subjective norms and behavioral control.

\section{Recommendations}

Because of the limitations of the study, the results of the study cannot provide a detailed description of the entrepreneurial education interventions of each individual. Longitudinal research is required to measure the persistence of entrepreneurial education in each individual. Future research needs to examine entrepreneurial behavioral factors specifically to gain deeper insight and create a better model of entrepreneurship education.

\section{REFERENCES}

Ajzen I. 2005. Attitudes, Personality and Behavior. Berkshire: McGraw-Hill.

Ajzen I, Sheikh S. 2016. Action versus inaction: anticipated affect in the theory of planned behavior: Erratum. Journal of Applied Social Psychology 46(5): 313-314.

Arnis N. Baga L M, Burhanuddin. 2018. The effect of entrepreneurial behavior on salted fish business performance at muara angke. Indonesian Journal of Business and Entrepreneurship 4(3): 217-226. https://doi.org/10.17358/ijbe.4.3.217.

Armitage CJ, Conner M. 2001. Efficacy of the theory of planned behaviour: a meta-analytic review. British Journal of Social Psychology 40(4): 471-499.

Bae TJ, Qian S, Miao C, Fiet JO. 2014. The relationship between entrepreneurship education and entrepreneurial intentions: a meta-analytic review. Entrepreneurship Theory and Practice 38(2): 217-254. https://doi.org/10.1111/ etap. 12095.

FayolleA, GaillyB.2015.The impactofentrepreneurship education on entrepreneurial attitudes and intention: hysteresis and persistence. Journal of Small Business Management 53(1): 75-93. https://doi.org/10.1111/jsbm.12065.

Ferreira JJ. et al. 2012. A model of entrepreneurial intention: an application of the psychological and behavioral approaches. Journal of Small Business and Enterprise Development 19(3): 424-440. https://doi.org/10.1108/14626001211250144.

Graevenitz Gv, Harhoff D, Weber R. 2010. The effects of entrepreneurship education. Journal of Economic Behavior \& Organization 76(1): 90112. https://doi.org/10.1016/j.jebo.2010.02.015.

Guerrero M,Urbano D, Fayolle A. 2014. Entrepreneurial activity and regional competitiveness: evidence from European entrepreneurial universities. The Journal of Technology Transfer 41: 105-131.

Hair J et al. 2010. Multivariate data analysis. Seventh edition ed. New Jersey: Pearson Prentice Hall.

Hanushek EA, Woessmann L. 2007. The Role of Education Quality for Economic Growth. World Bank Policy Research Working Paper 4122. https://doi.org/10.1596/1813-9450-4122.

Imaroh TS. 2014. Pendidikan Entrepreneurship sebagai Strategi Peningkatan Daya Saing Bangsa dalam Menghadapi AEC. Jakarta: Lemhanas. 
Kautonen T, Gelderen Mv, Fink M. 2015. Robustness of the theory of planned behavior in predicting entrepreneurial intentions and actions. Entrepreneurship and Practice 39(3): 655-674. https://doi.org/10.1111/etap.12056.

Kolvereid L, Isaksen E. 2006. New business start-up and subsequent entry into self-employment. Journal of Business Venturing 21(6): 866-885. https://doi.org/10.1016/j.jbusvent.2005.06.008.

Küttim M, Kallaste M, Venesaar U, Kiis A. 2014. Entrepreneurship education at university level and students' entrepreneurial intentions. Procedia - Social and Behavioral Sciences 110: 658-668.

Liñán F, Chen Y. 2006. Testing the Entrepreneurial Intention Model on a Two-Country. Departament d'Economia de l'Empresa.

Liñán F, Rodríguez-Cohard JC, Rueda-Cantuche JM. 2011. Factors affecting entrepreneurial intention levels: a role for education. International Entrepreneurship and Management Journal 7(2): 195-218. https://doi.org/10.1007/s11365010-0154-z.

Maes J, Leroy H, Sels L. 2014. Gender differences in entrepreneurial intentions: a TPB multi-group analysis at factor and indicator level. European Management Journal 32(5): 784-794.

Matlay H. 2008. The impact of entrepreneurship education on entrepreneurial outcomes. Journal of Small Business and Enterprise Development 15(2): 382-396. https://doi. org/10.1108/14626000810871745.

Oosterbeek H, Praag Mv, Ijsselstein A. 2009. The impact of entrepreneurship education on entrepreneurship skills. European Economic
Review 54(3): 442-454.https://doi.org/10.1016/j. euroecorev.2009.08.002.

Paco AD, Ferreira J, Raposo M, Rodrigues RG, Dinis A. 2011. Entrepreneurial intention among secondary students: findings from Portugal. International Journal of Entrepreneurship and Small Business 13(1): 92-106.

Pittaway L, Cope J. 2007. Entrepreneurship education: a systematic review of the evidence. International Small Business Journal 25(5): 479-510. https:// doi.org/10.1177/0266242607080656.

Solesvik M, Westhead P, Kolvereid L, Matlay H. 2012. Student intentions to become self-employed: the Ukrainian context. Journal of Small Business and Enterprise Development 19(3): 441-460. https://doi.org/10.1108/14626001211250153.

Soutaris V, Zerbinati S, Al-laham A. 2007. Do entrepreneurship programmes raise entrepreneurial intention of science and engineering students? The effect of learning, inspiration and resources. Journal of Business Venturing 22(4): 566 - 591. https://doi. org/10.1016/j.jbusvent.2006.05.002.

Thompson ER. 2009. Individual entrepreneurial intent: construct clarification and development of an internationally reliable metric. Entrepreneurship Theory and Practice 33(3): 669-694. https://doi. org/10.1111/j.1540-6520.2009.00321.x.

Zhang Y, Duysters G, Cloodt M. 2014. The role of entrepreneurship education as a predictor of university students' entrepreneurial intention. International Entrepreneurship and Management Journal 10(3): 623-641. https://doi.org/10.1007/ s11365-012-0246-z. 